8 - ORIGINAL ARTICLE

EXPERIMENTAL ORTHOPAEDIC SURGERY

\title{
A comparative study of the areas of osteochondral defects produced in femoral condyles of rabbits treated with sugar cane biopolymer gel ${ }^{1}$
}

\author{
Paulo Cezar Vidal Carneiro de Albuquerque', José Lamartine de Andrade Aguiar", Nicodemos Teles de Pontes Filho ${ }^{\mathrm{III}}$, \\ Roberto José Vieira de Mello ${ }^{\mathrm{I}}$, Clarissa Miranda Carneiro de Albuquerque Olbertz ${ }^{\mathrm{v}}$, Paula Eduarda Miranda Carneiro \\ de Albuquerque ${ }^{\text {V }}$ Silvânia Tavares Paz ${ }^{\text {VI }}$, Alessandro Henrique da Silva Santos ${ }^{\text {VII }}$, Carina Scanoni Maia ${ }^{\text {VIII }}$ \\ DOI: http://dx.doi.org/10.1590/S0102-865020150110000008 \\ IFellow Master degree, Postgraduate Program in Surgery, Associate Professor, Department of Surgery, Universidade Federal de Pernambuco (UFPE), \\ Recife-PE, Brazil. Scientific and intellectual content of the study. \\ IIAssociate Professor, Department of Sugery, UFPE, Recife-PE, Brazil. Manuscript preparation. \\ IIIAssociate Professor, Department of Pathology, UFPE, Recife-PE, Brazil. Manuscript writing, supervised all phases of the study. \\ ${ }^{\text {IV }}$ Full Professor, Department of Pathology, UFPE, Recife-PE, Brazil. Conception of the study, critical revision. \\ ${ }^{\vee}$ Graduate student, School of Medicine, UFPE, Recife-PE, Brazil. Acquisition and interpretation of data. \\ ${ }^{\mathrm{V}}$ Laboratory technician, UFPE, Recife-PE, Brazil. Technical procedures. \\ VIIAssistant Professor, Department of Nursing, UFPE, Recife-PE, Brazil. Statistical analysis.

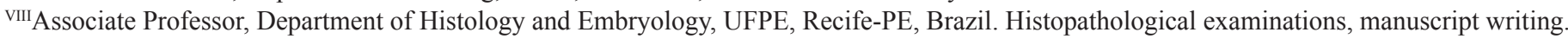

\begin{abstract}
PURPOSE: To assess the histological response of damaged osteochondral tissue in the femoral condyles of rabbits after repairing the wounds with sugar cane biopolymer gel - compared to the control group.

METHODS: The study investigated 16 New Zealand rabbits, at 90, 120 and 180 days after surgery. In all the animals, a lesion of 3.2 $\mathrm{mm}$ in diameter and $4 \mathrm{~mm}$ deep was induced in each right and left femoral condyle. Each animal has provided both knees, divided into medial and lateral condyle, resulting in 64 samples. 32 knees were divided into two groups: Right knee, medial and lateral condyles, filled with biopolymer; Left knee, medial and lateral condyles, unfilled. The anatomical specimens were removed, and subjected to histological techniques and morphometric and statistical analysis.

RESULTS: In all the periods of the group under study an inflammatory reaction mediated by giant cells and mononuclear cells was found, while in the control group there was early healing produced by fibroblasts and few mononuclear cells with statistical significance between groups.
\end{abstract}

CONCLUSION: The biopolymer gel caused an inflammatory reaction mediated by giant cells and mononuclear cells while the control group there was cicatrization mediated by fibroblasts.

Key words: Osteogenesis. Cartilage. Histology. Biopolymers. Rabbits. 


\section{Introduction}

Tissue engineering has been defined as an interdisciplinary field that applies the principles of engineering and the life sciences to the development of biological substitutes that restore, maintain, or improve tissue function ${ }^{1}$.

Various materials have been developed as scaffolds for tissue engineering, including metals, ceramics, and polymers ${ }^{2}$. Among various biomaterials, great importance has been given to polymers which, according to the National Association of Biosecurity, are classified structurally as polymeric materials, such as polysaccharides, polyesters or polyamides ${ }^{3-5}$. Biocompatibility and biodegradability should be pursued with greater efficiency in every material used ${ }^{1,2}$. Biopolymers are obtained through renewable sources of carbon, such as carbohydrates derived from sugar cane (Saccharum officinarum L.), corn, potatoes, wheat or beetroot ${ }^{6-12}$. While looking for new advances, an extracellular polysaccharide was obtained by fermenting sugar cane molasses using the microorganism Zoogloea sp, which had already been identified in the department of antibiotics at the Federal University of Pernambuco (UFPE). The biopolymer synthesized by this bacterium has the physical characteristics of purity, elasticity and flexibility ${ }^{1,13-16}$. It showed low cytotoxidity and biocompatibility in experimental studies ${ }^{17}$. Several biological and synthetic materials, including polymers have been applied in osteochondral tissue as reparative substrate due to their low regeneratival capacity ${ }^{18-29}$. The aim of this study was to analyse the histology of the osteochondral defects produced in the femoral condyle of rabbits, which had been filled with sugar cane biopolymer gel (SCBG), after 90, 120 and 180 days, as compared with a control group.

\section{Methods}

They were provided by the vivarium of the Center for Experimental Surgery of the Federal University of Pernambuco (UFPE). All procedures were conducted under veterinary supervision and approved by the Ethics Committee on Animal Experimentation of the Center for Biological Sciences (UFPEEAEC).

For the purpose of this research study 16 rabbits were studied. The use of laboratory animals followed the ethical code for animal experimentation of the Council for International Organization of Medical Sciences and the Brazilian College on Animal Experimentation. They were white, young adults of the New Zealand breed, between six and seven months old, weighing between 2 and $2.5 \mathrm{~kg}$, with no changes in their locomotor apparatus. The animals were confined in metal cages, were able to roam freely and were fed with standard pellets and water ad libitum.

\section{Surgical technique}

The rabbits underwent general anaesthesia with 5\% ketamine hydrochloride in a dosage of $50 \mathrm{mg} / \mathrm{kg}$, associated with $10 \%$ chloral hydrate in a dosage of $0.5 \mathrm{ml} / \mathrm{kg}$ and complemented with local anaesthesia: $5 \mathrm{ml}$ of $2 \%$ xylocaine diluted in $9 \mathrm{ml}$ of distilled water.

After asepsis of the surgical area, a medial patellofemoral incision was made, followed by an arthrotomy and lateral dislocation of the patella to get a better view. With the knee bent, each femoral condyle was exposed and with the aid of metallic trephine, osteochondral defects of $3.2 \mathrm{~mm}$ in diameter and $4.0 \mathrm{~mm}$ deep were produced in the femoral condyles of each knee. The animals were divided into two random groups: Study group, right knee, the medial and lateral condyles were filled with SCBG; and Control group, left knee, medial and lateral condyles, where the defects were left unfilled. The 16 rabbits were euthanized at 90 (six rabbits), 120 (five rabbits) and 180 days (five rabbits) after surgery. Each knee supplied two samples for histological analysis, one for medial condyle and another for lateral condyle. The group of 90 days was 24 samples, the group of 120 days was 20 samples, and the group of 180 days was 20 samples. 32 knees were divided into two groups: Right knee, medial and lateral condyles, filled with biopolymer; Left knee, medial and lateral condyles, unfilled.

\section{Histological analysis}

The anatomical specimens were resected after having been immersed in Bouin's solution for 48 hours, then decalcified using a solution of $8 \%$ hydrochloric and formic acids in equal amounts for 48 hours, which then was followed by the usual histolic techniques of dehydration, bleaching, sizing, staining and embedding in paraffin.

Cuts with microtome using a Leica microtome RM 2125 RT, were made along the sagital axis of the distal femur, from 4 to $7 \mu \mathrm{m}$, and stained with hematoxylin-eosin and Masson's tricrome. An Opton ${ }^{\circledR}$ optical microscope Opton ${ }^{\circledR}$ was used, with magnifications of $\times 40, \times 100$ and $\times 400$, for qualitative and quantitative analysis of the cellularity in the histological sections of each animal in both the study and control groups. 


\section{Morphometric analysis}

For each tissue analyzed, five random fields were studied, with magnification of $\mathrm{x} 400$, totaling 20 fields per group studied. Photographs were taken using a Motic $1000^{\circledR}$ camera attached to the Opton ${ }^{\circledR}$ optical microscope and stored in the image analysis software - Motic Images Plus ${ }^{\circledR}$.

After obtaining the photographs, a morphometric study was conducted and the density of giant cells in each field evaluated, the count being made automatically using the Mesurin Pro $^{\circledR}$ software. Density was defined as the number of cells per area in $\mu \mathrm{m}^{2}$. Mean densities of each histological section were taken for comparative statistical study.

\section{Statistical analysis}

For the statistical analysis the number of giant cells present was quantified in each microscopic field of the histological sections obtained after 90, 120 and 180 days, for the study group. The mean, median and standard deviation were calculated and the nonparametric Kruskal-Wallis test was applied for comparison between the averages found at each period. Statistical analysis of the material was conducted using a significance level of $5 \%$, $\mathrm{p}<0.05$. For the statistical analysis of the number of inflammatory cells present, the minimum, maximum, mean, median, standard deviation and the number of estimated average confidence interval were calculated. The Kolmogorov-Smirnov test was used to evaluate the normality of cells observed. In cases where normality was not observed, the Mann-Whitney test was used to compare the two groups and the nonparametric Kruskal-Wallis test was applied for comparison among three or more groups. Statistical analysis of all the material was conducted using a significance level of 5\%, $\mathrm{p}<0.05$.

\section{Results}

The result of counting the number of giant cells in each microscopic field of the histological sections at 90, 120 and 180 days, for the animals in the study group, is found in Table 1. Histological analysis was performed by using the qualitative method and the variables related to the nature of the repaired tissue were evaluated.

TABLE 1 - Results of counting the number of giant cells present in the study group and mean comparison test at 90,120 and 180 days $(\mathrm{p}<0.05)$.

\begin{tabular}{ccccccc}
\hline Periods (days) & Minimum & Maximum & Mean & Median & $\begin{array}{c}\text { Standard } \\
\text { Deviation }\end{array}$ & IC $(95 \%)$ \\
\hline 90 & 2 & 10 & 5.65 & 6.00 & 2.13 & $4.65-6.65$ \\
120 & 1 & 10 & 5.75 & 6.50 & 2.79 & $4.44-7.06$ \\
180 & 0 & 10 & 5.05 & 4.50 & 2.68 & $3.79-6.31$ \\
Total & 0 & 10 & 5.48 & 5.50 & 2.53 & $4.83-6.14$ \\
\hline
\end{tabular}

${ }^{1} \mathrm{p}$ value of the Kruskal-Wallis Test $(\mathrm{p}<0.05)$

The result of counting the number of inflammatory cells observed a predominance of mononuclear cells (monocytes/ macrophages and lymphocytes). Table 2 shows a descriptive analysis of the number of mononuclear cells under the study period.

TABLE 2 - Descriptive analysis of the number of mononuclear cells under the study period.

\begin{tabular}{ccccccc}
\hline Periods (days) & Minimum & Maximum & Mean & Median & $\begin{array}{c}\text { Standard } \\
\text { Deviation }\end{array}$ & IC $(95 \%)$ \\
\hline 90 & 4 & 10 & 7.0 & 7.0 & 1.3 & $6.6-7.4$ \\
120 & 2 & 7 & 4.5 & 4.0 & 1.3 & $4.1-4.9$ \\
180 & 0 & 8 & 3.8 & 4.0 & 1.9 & $3.2-4.4$ \\
Total & 0 & 10 & 5.1 & 5.0 & 2.0 & $4.7-5.5$ \\
\hline
\end{tabular}

$\mathrm{p}$ value of the Kruskal-Wallis Test $(\mathrm{p}<0.05)$. 
Table 3 shows the mean and standard deviation of the number of mononuclear cells according to the study period and the group evaluated. At 90, 120 and 180 days, the average number of mononuclear cells was higher in the group with biopolymer than in the control group. Moreover, the distribution comparison test was not significant after
90 days of treatment, indicating that the distribution of mononuclear cells is identical at this stage of treatment. However, after 120 days and 180 days, there was a significant difference in the distribution of mononuclear cells between the control group and the biopolymer group.

TABLE 3 - Mean and standard deviation of the number of mononuclear cells according to the period of the study and the evaluated group.

\begin{tabular}{|c|c|c|c|}
\hline \multirow{2}{*}{ Periods (days) } & \multicolumn{2}{|c|}{ Rated Group } & \multirow[b]{2}{*}{ p-value ${ }^{1}$} \\
\hline & Control & Biopolimers & \\
\hline 90 & $6.6 \pm 1.3$ & $7.4 \pm 1.3$ & 0.160 \\
\hline 120 & $4.0 \pm 0.9$ & $5.0 \pm 1.4$ & 0.009 \\
\hline 180 & $2.8 \pm 1.4$ & $4.6 \pm 1.8$ & $<0.001$ \\
\hline Total & $4.5 \pm 2.0$ & $5.7 \pm 1.9$ & 0.001 \\
\hline
\end{tabular}

$\mathrm{p}$ value of the Mann-Whitney Test $(\mathrm{p}<0.05)$

Results of the histological analysis of the study group after 90 days

In Figure 1, a chronic inflammatory reaction with a foreign body bypassing the SCBG is shown. The cellular elements were predominantly monocytes/macrophages, lymphocytes, giant inflammatory cells and, to a lesser extent, neutrophils. Besides this cellular composition, a reaction of the foreign body type in the form of giant cells was seen to be in contact with the SCBG.
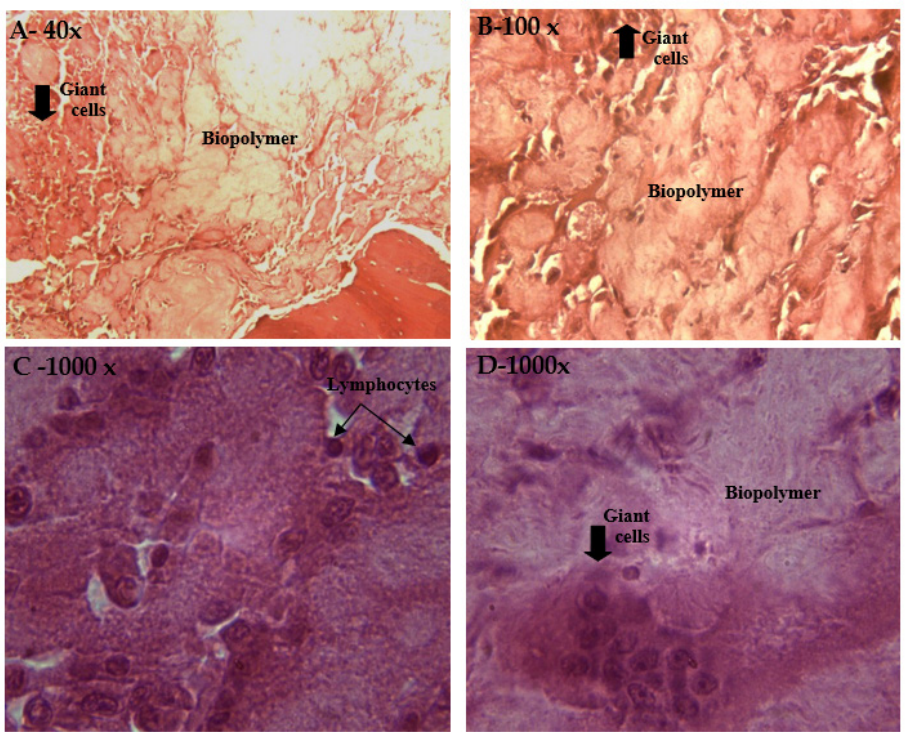

FIGURE 1 - Photomicrographs of a histological analysis of the study group 90 days after the defects were filled (A, B, C and D) with biopolymer, lymphocytes and giant cells. Notice the presence of a larger amount of SCBPG in the extracellular medium.

\section{Results of the histological analysis of the control} group after 90 days

In Figure 2, an intense fibrous reaction, with vessels and complete closure of the lesion is observed without the presence of cells characteristic of the inflammatory process.
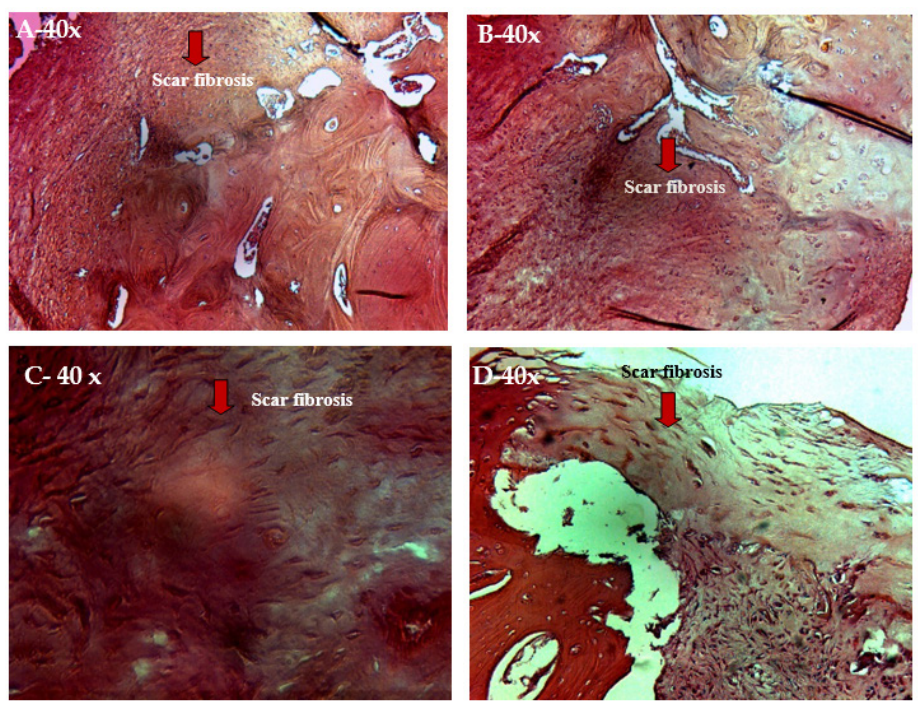

FIGURE 2 - Photomicrograph of a histological section analysis of the control group after 90 days with unfilled defects (A, B, C and D). Fibrotic scarring. Observe the proliferation of fibroblasts in the defect produced.

Results of the histological analysis of the study group after 120 days

In Figure 3, a chronic inflammatory reaction of the foreign body type is observed bypassing the SCBG. The predominant 
cellular elements are monocytes, macrophages, lymphocytes, giant cells and, to a lesser extent, neutrophils. Besides this cellular composition, there is the presence of SCBG phagocytized by giant cells.
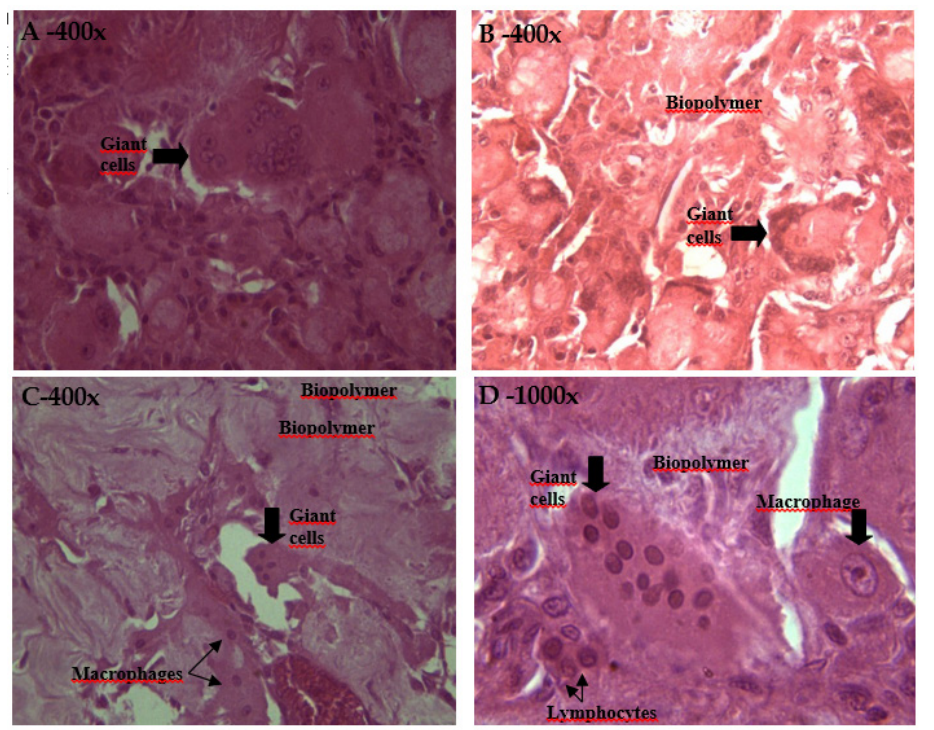

FIGURE 3 - Photomicrographs of a histological section analysis of the group under study 120 days after the defects were filled (A, B, C and D). Observe giant cells with SCBG inside them and macrophages and lymphocytes (C and $\mathbf{D})$.

\section{Results of the histological analysis of the control group after 120 days}

In Figure 4, intense fibrous reaction with vessels and closing of the defect is found without the presence of characteristic cells of the inflammatory process.

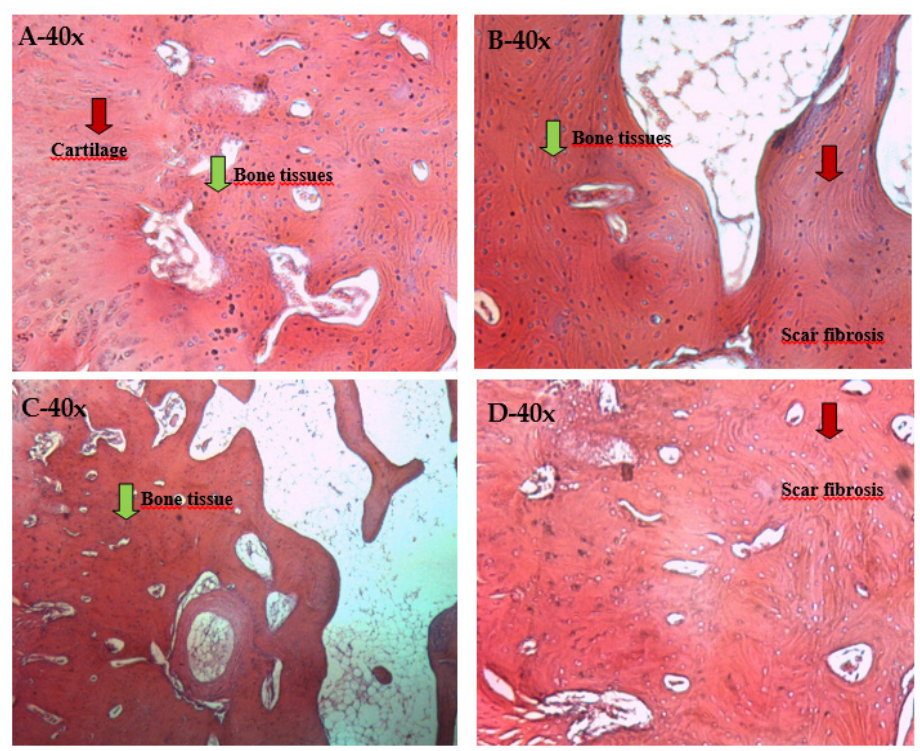

FIGURE 4 - Photomicrographs of a histological analysis of the control group after 120 days with unfilled defects $(\mathbf{A}, \mathbf{B}, \mathbf{C}$ and $\mathbf{D})$. Observe the fibrotic scarring on the defect produced.
Results of the histological analysis of the study group after 180 days

In Figure 5, the presence of giant cells indicates a reaction of the foreign body $-\mathrm{SCBG}$ - implanted. The giant cells rest on the fibrovascular structure.

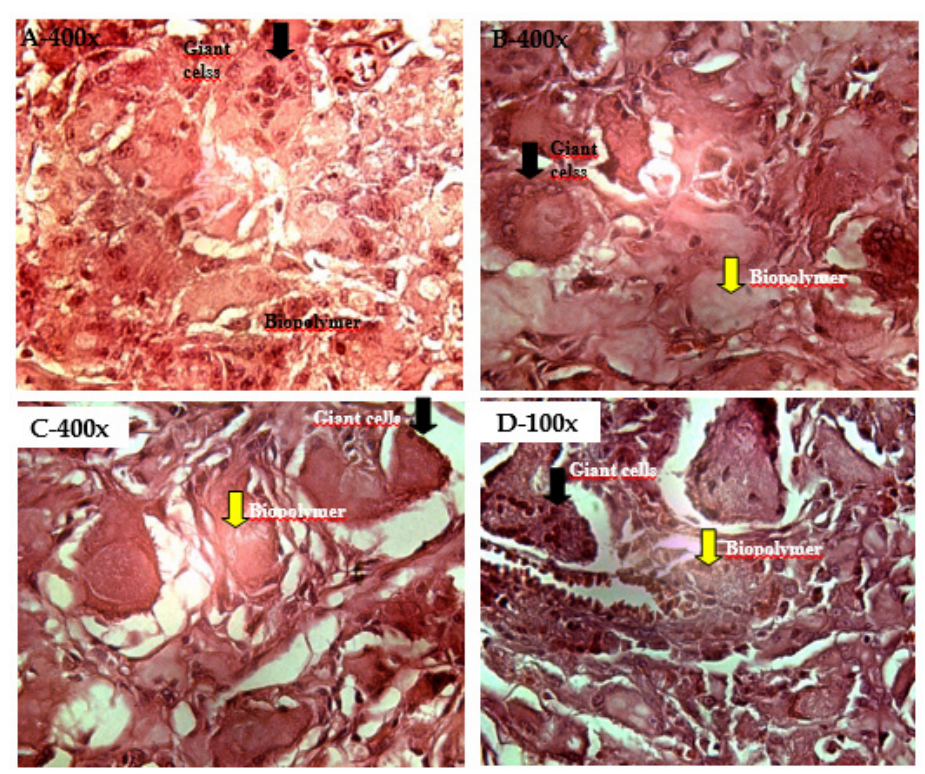

FIGURE 5 - Photomicrographs of a histological analysis of the group under study, 180 days after the defects were filled (A, B, C and D). Observe the presence of SCBG within the giant cells.

In Figure 6, the intense fibrous reaction, with vessels, is noted, thus characterizing a healing reaction with complete closure of the lesion produced.
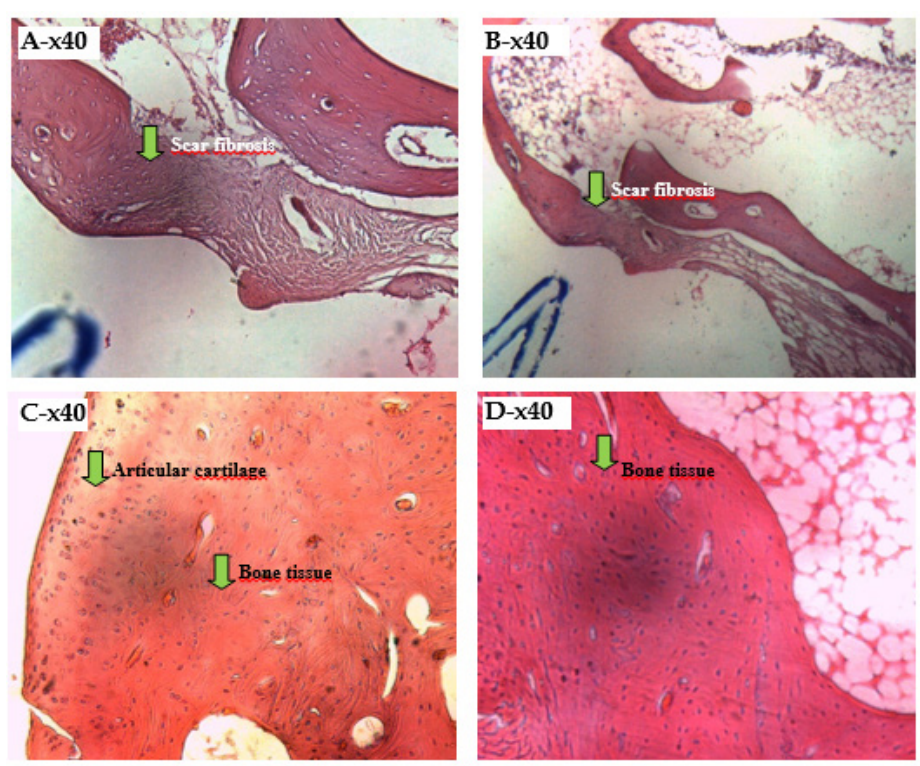

FIGURE 6 - Photomicrographs of a histological analysis of the control group, 180 days with unfilled defects (A, B, C and D). Observe the fibrotic scarring in the defect produced around the bone tissue and the articular cartilage. 


\section{Discussion}

Recent studies demonstrate that osteochondral tissue inflammation mediated by giant cells, arising from the use of biopolymers, is often found in defects filled with these materials. The resolution of the inflammation takes place when a granulation tissue is formed, in which macrophages, fibroblasts and neovascularization are identified ${ }^{1,30-35}$. However, in this study we found no characteristic granulomatous reaction, even with reaction mediated by giant cells, mononuclear leukocytes and neovascularization.

As above fact may be explained by the infiltration of inflammatory cells in the biopolymer once with 90,120 and 180 days is difficult to find typical granulomas.

In a study of bone repair in the nasal dorsum of capuchin monkeys with castor beans biopolymer the presence of inflammatory cells and foreign body was not found after 270 days of surgery ${ }^{36}$. However, this fact can be explained by the longer time compared to ours which was no longer than 180 days.

Research on biopolymers of chitosan based with or without hydroxyapatite showed fibrosis in the study group and intense cellular reactions, represented by fibroblasts, osteoblasts and osteoclasts with only 30 days after surgery ${ }^{37}$.

In this research, the fibrosis was observed only in the control group, however, the evaluation period differs from the author above.

The evolution depends on whether the implanted biopolymer acts only as a foreign body or whether it also acts as an immunogenic material. In the first case, there is the formation of a fibrous capsule surrounding the material, isolating it from the body. In the second, there is intensification of the inflammatory reaction and rejection of the material. The results showed that few lymphocytes were present, and did not show any cell destruction, though they did present a reaction mediated by giant cells $s^{1,2,30-35}$.

When analyzing the results, inflammatory cells with giant cells and mononuclear cells were found at 120 and 180 days. This persistence leads to the belief that there is a peak time for the inflammatory reaction with subsequent decline after the defect has healed, indicated by the fact that the histological preparations showed no immunogenic halo in the surrounding area. Moreover, an acute inflammatory reaction associated with the presence of an implanted biopolymer is triggered in any situation following implantation of any biomaterial in a living organism, known with the formation of an acute inflammatory response mediated by macrophages, monocytes, protein adsorption, fusion of macrophages and formation of giant cells, featuring a foreign body reaction for a period 2 to 4 weeks $^{38}$.

The study found that the highest average number of giant cells was observed in the study group at 120 days (5.75), and the lowest at 180 days (5.05). Moreover, the highest median was also found in the study group at 120 days. The largest deviation was observed in the study group at 120 days, indicating that this is the time which has the greatest dispersion in the number of giant cells. Even after noting these differences in the mean number of giant cells, in the three periods studied, the mean comparison test did not appear significant.

The statistical Kruskal-Wallis test showed no difference in the number of giant cells found at 90, 120 and 180 days, and found a decrease in the number of mononuclear cells, suggesting a non-progression of the inflammatory process.

There is an extensive list of polymers that have been assessed for use in bone tissue replacement, both natural and synthetic. Natural polymers such as chitosan, alginate and hyaluronic acid as well as proteins such as collagen, fibrin and silk, show promise due to their inherent biocompatibilities and biodegradabilities ${ }^{30,31}$

In addition to the features previously cited, bone substitute scaffolds they must mechanically sound, have porous structure, be economical to make, and allow easy fabrication into the final preforms ${ }^{39,40}$.

The main limitations of natural polymers are their low mechanical strength and somewhat unpredictable degradation rate. In contrast, synthetic polymers can be engineered to degrade at a tightly controlled rate and can exhibit mechanical and compressive strength similar to bone However, as they are synthetic, these polymers can elicit an immune response and the by-products of degradation are acidic, which can lead to inflammation ${ }^{30,31}$.

Bone substitute development is a multidisciplinary research field, and significant improvements in current options, and new developments, are likely to increase our basic understanding of the underlying principles ${ }^{41}$.

Thus, although there is no a general consensus that there is yet no entirely satisfactory filling material for osteochondral defects, The use of biomaterials, such as biodegradable and bioabsorbable polymer, has an increasing role in the medical therapeutic arsenal ${ }^{42}$.

The sugar cane biopolymer is classified as a natural biomaterial derived from a bacterium and showed no rejection during the study period, therefore, can become a future option in the repair of cartilage and / or bone tissue. 


\section{Conclusions}

The application of sugar cane biopolymer to fill the osteochondral defects produced in the femoral condyles of rabbits, led to an inflammatory reaction mediated mainly by giant cells. In the control group, where the defects were not filled, there was fibrotic scarring with low presence of cells characteristic of the inflammatory process. There was no rejection of SCBP during the study period, but more research is needed in order to elucidate other possible properties of said biopolymer, eg, mechanical properties, porosity, osteoinduction capacity and others.

\section{References}

1-Middlteton JC, Tipton AJ. Synthetic biodegradable polymers as orthopedic devices. Biomaterials. 2000 Dec;21(23):2335-46. PMID: 11055281 .

2-Bao Lin GUO, Peter XMA. Synthetic biodegradable functional polymers for tissue engineering: a brief review. Sci China Chem. 2014. Apri 1;57(4):490-500. doi: 10.1007/s11426-014-5086-y.

3-Ma PX. Biomimetic materials for tissue engineering. Adv Drug Delivery Rev. 2008;60:184-98. doi: 10.1016/j.addr.2007.08.041.

4-Hench L, Polak J. Third generation biomedical materials. Science. 2002 Feb;8(295):1014-7. doi: 10.1126/science.1067404.

5-Navarro M, Michiardi A, Castanõ O, Planell JA. Biomaterials in orthopaedics. J R Soc Interface. 2008 Jul;5(27):1137-58. doi: 10.1098/rsif.2008.0151.

6-Beedle MP, Kennedy JF, Melo FAD, Lloyd LL, Medeiros VA. Cellulosic exopolysaccharide produced from sugar cane molasses by a Zooglea sp. Carbohydr Polym. 2000 Ago;42(4):375-83. doi: 10.1016/S0144-8617(99)00179-4.

7-Aguiar J, Lins E, Marques S, Coelho A, Rossiter R, Melo R. Sugar cane biopolymer patch in femoral artery angioplasty in dogs. Acta Cir Bras. 2007 Mar-Apr;22(Supl. 1):77-81. doi: 10.1590/S010286502007000700015.

8-Anderson JM, Rodrigues A, Chang DT. Foreign body reaction to biomaterials. Semin Immnuol. 2008 Apr;20(2):86-100. PMID: PMC2327202.

9-Campana V, Milano G, Pagano E, Barba M, Cicione C, Salonna G, Lattanzi W, Logroscino G. Bone substitutes in orthopaedic surgery. Basic Sci Clin Pract. 2014 May;25(10):2445-61. doi: 10.1007/ s10856-014-5240-2.

10-Johnson LL, Verioti C, Gelber J, Spector M, D’Lima D, Pittsley A. The pathology of the end-stage osteoarthritic lesion of the knee: Potential role in cartilage repair. Knee. 2011 Dec;18(6):402-6. doi: 10.1016/j.knee.2010.07.012.

11-Flanigan DC, Harris JD, Brockmeier PM, Siston RA. The effects of lesion size and location on subchondral bone contact in experimental knee articular cartilage defects in a bovine model. Arthroscopy. 2010 Dec;26(12):1655-66. doi: 10.1016/j.arthro.2010.05.017.

12- Ferreira BM, Steffen AM, Cardoso TP, Alberto-Rincon MC, Duek EAR. Haste intramedular polimérica bioreabsorvível (PLLA/PHBV) para uso na recuperação de fraturas ósseas. Poli Cienc Tecnol. 2008 Jun;18(4):312-9. doi: 10.1590/S0104-14282008000400010.

13-Aguiar J, Lins E, Marques S, Coelho A, Rossiter R, Melo R. Sugar cane biopolymer patch in femoral artery angioplasty in dogs. Acta Cir Bras. 2007 Mar-Apr;22(Supl. 1):77-81. doi: 10.1590/S010286502007000700015 .
14-Marques SRB, Lins EM, Aguiar JLA, Albuquerque MCS, Rossiter RO, Montenegro LT, Vieira RJ. Um novo substituto vascular: arterioplastia femoral em cães com remendo de membrana de bipolímero de cana-de-açúcar - avaliação hemodinâmica e histológica. J Vasc Bras. 2007 Dec;6:309-15. doi: 10.1590/S167754492007000400003.

15-Akagawa Y, Kubo T, Karetake K, Hayashi K, Doi K, Matsuura A, Morita K, Takeshita R, Yuan Q, Tabata Y. Initial bone regeneration around fenestrated implants in Beagle dogs using basic fibroblast growth factor-gelatin hydrogel complex with varying biodegradation rates. J Prosthodont Res. 2009 Jan;53(1):41-7. doi: 10.1016/j.jpor.2008.08.009.

16-Coelho MCOC, Carrazoni PG, Monteiro VLC, Melo FAD, Mota R, Tenório Filho F. Biopolímero produzido a partir de cana de açúcar para cicatrização cutânea. Acta Cir Bras. 2002 Jan;17 (suppl 1):1-7. doi: 10.1590/S0102-86502002000700003.

17-Castro C, Aguiar J, Melo F, Silva W, Marques E, Silva D. Citotoxicidade de biopolímero de cana-de-açúcar. An Fac Med Univ Fed Pernamb. 2004 Jun;49(2):119-23.

18- Glowacki J, Mizuno S. Biomaterials in cartilage and bone tissue engineering. Curr Opln Orthop. 2004 Oct;15(5):347-5.

19-Ikeda R, Fujioka H, Nagura I, Kokubu T, Toyokawa N, Inui A, Makino T, Kaneko H, Doita M, Kurosaka M. The effect of porosity and mechanical property of a synthetic polymer scaffold on repair of osteochondral defects. Int Orthop. 2009 Jun;33(3):821-8. doi: 10.1007/s00264-008-0532-0.

20-Carlo EC, Borges APB, Pompermayer LG, Martinez MM, Eleotério RB, Nehme RC, Morato GO. Compósito para fabricação de implantes reabsorvíveis para osteossíntese: avaliação da biocompatibilidade em coelhos. Cienc Rural. 2009 Jan-Fev;39(1):135-40. doi: 10.1590/ S0103-84782008005000036.

21-Amiel D, Coutts D, Abel M, Stewart W, Harwood F, Akeson WH, Jolla LA. Rib perichondrial graft for repair of full-thickness articularcartilage defects. J Bone Joint Surg. 1985 Jul;67(6):911-20. PMID: 4019540.

22-Martin-Hernandez C, Cebamanos-Celma J, Molina-Ros A, BallesterJimenez JJ, Ballester-Soleda J. Regenerated cartilage produced by autogenous periosteal grafts: a histologic and mechanical study in rabbits under the influence of continuous passive motion. Arthroscopy. 2010 Jan;26(1):76-83. doi: 10.1016/j. arthro.2009.07.005.

23-Brittberg M. Autologous chondrocyte implantation - Technique and long-term follow-up. Injury. 2008 Apr;39(suppl 1):40-9. doi: 10.1016/j.injury.2008.01.040.

24-Glowacki J, Mizuno S. Biomaterials in cartilage and bone tissue engineering. Curr Opln Orthop. 2004 Oct;15(5):345-7.

25-Carlo EC, Borges APB, Pompermayer LG, Martinez MM, Eleotério RB, Nehme RC, Morato GO. Compósito para fabricação de implantes reabsorvíveis para osteossíntese: avaliação da biocompatibilidade em coelhos. Cienc Rural. 2009 Jan-Fev;39(1):135-40. doi: 10.1590/ S0103-84782008005000036.

26-Sassioto MCP, Cardoso Filho N, Facco GG, Sodrés ST, Neves N, Purisco SU, Farias AG. Efeito da Casearia sylvestris no reparo ósseo com matriz óssea bovina desvitalizada em ratos. Acta Cir Bras. 2004 Nov-Dez;19(6):637-41. doi: 10.1590/S0102-86502004000600010.

27-Fowler DE , Hart JM, Hart JA, Miller MDJ. Responses in vivo to purified poly(3-hydroxybutyrate-co-3-hydroxyvalerate) implanted in a murine tibial defect model. J Biomed Mater Res A. 2009 Dec;91(3):845-54. doi: 10.1002/jbm.a.32238.

28-Emans PJ, van Rhijn LW, Welting TJM, Cremers A, Wijnands N, Spaapen F, Voncken JW, Shastri VP. Autologous engineering of cartilage. Proc Natl Acad Sci U S A. 2010 Feb;107(8):3418-23. doi: 10.1073/pnas.0907774107. 
29-Albuquerque PCVC, Aguiar JLA, Santos SM, Filho NP, Mello RJV, Costa MLC, Albuquerque CMC, Almeida TM, Santos AHS, Silva JC. Comparative study of the areas of osteochondral defects produced in the femoral condyles of rabbits treated with gel of sugar cane biopolymer. Acta Cir Bras. 2009 Apr;26(5):383-6. doi: 10.1590/S0102-86502011000500010.

30-Böstman OMO, Laitinen M, Tynninen O, Salminen ST,. Pihlajamäki HK. Tissue restoration after resorption of polyglycolide and polylaevo-lactic acid screws. J Bone Surg. 2005 Nov;87(11):1575-80. doi: 10.1302/0301-620x.87B11.16520.

31-Kulkarni RK, Moore EG, Hegyeli AF, Leonard F. Biodegradable poly (lactic acid) polymers. J Biomed Mater Res. 1971 May;5(3):169-81. PMID: 5560994.

32-Mendes PRS, Bins-Ely J, Lima EAS, Vasconcellos ZAA, d'Acampora AJ, Neves RE. Histological study on acute inflammatory reaction to polyurethane-coated silicone implants in rats. Acta Cir Bras. 2008 Nov;23(1):93-101. doi: 10.1590/S0102-86502008000100015.

33-Fowler DE , Hart JM, Hart JA, Miller MDJ. Responses in vivo to purified poly(3-hydroxybutyrate-co-3-hydroxyvalerate) implanted in a murine tibial defect model. J Biomed Mater Res A. 2009 Dec;91(3):845-54. doi: 10.1002/jbm.a.32238.

34-Silva D, Aguiar J, Marques A, Coelho A, Rolim Filho E. Miringoplastia com enxerto livre de membrana de biopolímero de cana-de-açúcar e fascia autóloga em Chinchilla laniger. An Fac Med Univ Fed Pernamb. 2006 Jun;51(1):45-51.

35-Tran RT, Thevenot P, Zhang Y, Gyawali D, Tang L, Yang J. Scaffold sheet design strategy for soft tissue engineering. Nat Mater. 2010 Feb;3(2):1375-89. doi: 10.3390/ma3021375.

36-Dias PCJ, Granato L, Ramalho LTO, Oliveira JA, Pretel H. Ricinus communis biocompatibility histological study in the nose of Cebus apella monkeys. Braz J Otorhinolaryngol. 2009 May/Jun;75(3):3505. doi: 10.1590/S1808-86942009000300007.

37-Azevedo ASA, Cavalcanti MJS, Lia MV, Nóbrega PIN, Sousa NOBS, Azevedo SS. Hydroxyapatite and chitosan isolated and associated with bone marrow in repair of bone tissue in rabbits. Histological and morfometric study. Cienc Rural. 2013 Jul;43(7):1265-70. doi: 10.1590/S0103-84782013000700019.
38-Anderson JM, Rodriguez A, Chang DT. Foreign body reaction to biomaterials Semin Immunol. 2008 April;20(2):86-100. PMID: 2327202.

39-Burg KJ, Porter S, Kellam JF. Biomaterial developments for bone tissue engineering. Biomaterials. 2000 Dec;21(23):2347-59. doi: 10.1016/S0142-9612(00)00102-2.

40-Goff T, Kanakaris NK, Giannoudis PV. Use of bone graft substitutes in the management of tibial plateau fractures. Injury. 2013 Jan;44 Suppl 1:S86-94. doi: 10.1016/S0020-1383(13)70019-6.

41-Swapan KS, Byong Taek Lee. Hard tissue regeneration using bone substittes: an update on innovations in materials. Korean J Intern Med. 2015 May;30(3):279-93. doi: 10.3904/kjim.2015.30.3.279.

42-Cardoso TP, Duek EAR, Amatuzzi MM, Caetano EB. Bioresorbable polymeric meniscal prosthesis: study in rabbits. Rev Bras Ortop. 2010 May/Jun;45 (3):247-59. doi: 10.1590/S0102-36162010000300006.

\section{Correspondence:}

Paulo Cezar Vidal Carneiro de Albuquerque

Departamento de Cirurgia, UFPE

Avenida Professor Moraes Rego, s/n

50670-901 Recife-PE Brasil

Tel.: (55 81)2126-3518

paulovidal_@hotmail.com

Received: July 13, 2015

Review: Sep 15, 2015

Accepted: Oct 19, 2015

Conflict of interest: none

Financial source: none

${ }^{1}$ Research performed at Animal Experimentation Unit, Research Center, Department of Surgery, School of Medicine, Universidade Federal de Pernambuco (UFPE), Recife-PE, Brazil. 